\title{
Feeding behavior of hummingbirds and perching birds on Erythrina speciosa Andrews (Fabaceae) flowers in an urban area, Londrina, Paraná, Brazil
}

\author{
Luciana Baza Mendonça ${ }^{1} \&$ Luiz dos Anjos ${ }^{2}$
}

\author{
${ }^{1}$ Corresponding author: Rua Serafim Nunes Diniz 311, 86200-000 Ibiporã, Paraná, Brasil. \\ E-mail: lucianabaza@yahoo.com.br \\ 2 Laboratório de Ornitologia e Bioacústica, Departamento de Biologia Vegetal e Animal, Universidade Estadual de Londrina. \\ Caixa Postal 6001, 86051-970 Londrina, Paraná, Brasil.
}

\begin{abstract}
Nine species of birds - seven hummingbirds (Trochilidae) and two Passeriformes - were observed visiting the flowers of Erythrina speciosa Andrews (Fabaceae), a hummingbird-pollinated species present on the campus of Londrina State University, Paraná State, Brazil. Nectar in bagged flowers bore little relationship with nectar in flowers opened to foragers either regarding quantity or diurnal pattern of availability. Birds were more frequent early in the morning and their activity on flowers further declined, apparently following the pattern of nectar availability. The manner to which birds probed the flowers and, in consequence, their role on pollination were greatly determined by morphological traits and approaching behavior of birds. E. speciosa seemed best suited for pollination by long-billed hummingbirds but some short to medium-billed species may play some role on its pollination.

KEY WORDS. Bird-plant interactions; nectar; nectarivory.
\end{abstract}

RESUMO. Comportamento alimentar de beija-flores e Passeriformes nas flores de Erytrhina speciosa Andrews (Fabaceae) em uma área urbana de Londrina, Paraná, Brasil. Nove espécies de aves - sete beija-flores (Trochilidae) e duas aves Passeriformes - foram observados visitando as flores de Erythrina speciosa Andrews (Fabaceae), uma espécie polinizada por beija-flores presente no campus da Universidade Estadual de Londrina, Paraná, Brasil. O néctar em flores ensacadas apresentou pouca relação com aquele em flores expostas aos visitantes, tanto em termos de quantidade como em temos de padrão diurno de disponibilidade. As aves foram mais freqüentes de manhã e sua atividade nas flores diminuiu no transcorrer do dia, coincidindo com o padrão de disponibilidade de néctar. $O$ comportamento de visita das aves e, em consequiência, sua atuação na polinização da espécie foram em grande parte determinadas por características morfológicas e comportamentais destas. $E$. speciosa parece ser adaptada para polinização por beija-flores de bicos longos, embora espécies com bicos de comprimento curto a médio possam ter algum papel em sua polinização.

PALAVRAS CHAVE. Interações aves-plantas; néctar; nectarivoria.

Nectar characteristics, patterns of secretion and availability, flower production, spatial arrangement, and morphological aspects of flowers and flower-visiting birds are important in order to understand the foraging behavior of birds on flowers (Feinsinger \& Colwell 1978, Waser 1983, Kearns \& Inouye 1993), as well as the consequences on pollen flow and seed set (Murcia \& Feinsinger 1996, Franceschinelli \& Bawa 2000).

Erythrina (Fabaceae) species have red to orange flowers, which produce copious nectar and are adapted for pollination by birds (NeILL 1987). In general, species belonging to this genus fall into two general categories of morphological and nectar traits, often viewed as adaptations to two different groups of birds: hummingbirds and perching birds. In those species adapted for hummingbirds, the floral architecture resembles tubular corollas of many gamopetalous hummingbird-pollinated flowers. However in Erythrina the pseudotube is not sealed in the ventral side (NeILL 1987). Inflorescences are organized in vertical axis, with flowers pointing outwards and sucrose is the prevailing sugar in the nectar (BAKER \& BAKER 1983, 1990, NeIlL 1987, Westerkamp 1990, BaKer et al. 1998). Conversely, most species pollinated by perching birds have more open corollas, with exposed sexual parts. The inflorescences axes are held horizontally and nectar is rich in hexose (FeINSINGER et al. 1979, Steiner 1979, Baker \& BaKer 1983, NeIll 1987, Westerkamp 1990, BAKER et al. 1998, RAgusa-NetTo 2002).

Erythrina speciosa Andrews is naturally found in Brazil, being widely used as an ornamental species. Its red flowers attract many birds and insects (Vitali-Veiga \& Machado 2000, 
Almeida \& Alves 2003, Mendonça \& Anjos 2005). Flowers produce sucrose-dominant nectar (BAKER \& BAKER 1983, 1990) and are typical of hummingbird-pollinated species (BAKER \& BAKER 1983, 1990, Almeida \& Alves 2003). However, passerine birds such as the Bananaquit - Coereba flaveola Linnaeus, 1758, the Brazilian Tanager - Ramphocelus bresilius Linnaeus, 1766, and the House Sparrow - Passer domesticus Linnaeus, 1758 have been recorded feeding at E. speciosa flowers (Vitali-Veiga \& Machado 2000, Almeida \& Alves 2003).

The main goals of the present study were to examine nectar consumption by birds in E. speciosa and evaluate their feeding behavior. The following questions were addressed: (1) what are the diurnal patterns of nectar production and standing crop? (2) Do the rates of bird visitation vary along the day? (3) What are the feeding behaviors of hummingbirds and perching birds at E. speciosa flowers? (4) How do morphological and behavioral features influence the role played by birds as pollinators?

\section{MATERIAL AND METHODS}

\section{Study Area}

The study was conducted in the campus of the Londrina State University ( 230 ha, $\left.23^{\circ} 19^{\prime} \mathrm{S}, 51^{\circ} 12^{\prime} \mathrm{W}\right)$, Paraná State, southern Brazil. The average annual temperature in the study site is $21^{\circ} \mathrm{C}$, varying from $27^{\circ} \mathrm{C}$ during summer (December to February) to $15.5^{\circ} \mathrm{C}$ during winter (June-August). The average annual precipitation is around $1600 \mathrm{~mm}$. A more detailed description of the campus can be found in MendonçA \& ANJos (2005). A cultivated population with five individuals which are a few meters from each other was chosen for observations. At the campus, the flowering period of $E$. speciosa occurs in the dry season, starting in June and extending until mid-September, with a major flowering burst in July. During the flowering peak, an average of 50 inflorescences per individual with 9-35 flowers each is found. Total corolla length is $70.6 \mathrm{~mm}(\mathrm{SD}=6.5, \mathrm{n}=14)$.

\section{Field Procedure}

Field work was carried on between July and August 2002. For the evaluation of cumulative production of nectar during the day, entire inflorescences were bagged with paper bags in the evening before measurements. A different set of flowers was sampled every two hours between 08:00 $\mathrm{h}$ and 16:00 h. At each sample, nectar volume was measured using micro-syringes (Hamilton) and nectar concentration was obtained with a pocket refractometer (Atago, 0-32\%). Nectar standing crop (both volume and concentration) throughout the day was also investigated. Sets of flowers exposed to visitors were sampled each three hours, between 08:00 $\mathrm{h}$ and 17:00 $\mathrm{h}$. When pertinent, the amount of sugar per flower was denoted in milligrams of sugar per flower or converted in joules per flower after DAFNI (1992).

Birds were observed (focal method, 35 field-hours) from 08:00 h until 17:30 h by 30 minutes surveillance sessions at 30 minutes intervals during the entire observation period. For each species of bird, we recorded the time, duration, and rate of visits (visits.30min ${ }^{-1}$ ), visiting behavior (the way birds probe the flowers for nectar), number of flowers probed per visit (only for hummingbirds), and agonistic interactions. Birds were classified in the following three categories according to their behavior (INOUYE 1980, 1983): (a) potential pollinators, when birds touched the sexual parts of flowers while feeding, (b) nectar thieves, when birds probed the flowers from its right aperture but did not touch the reproductive parts of flowers, precluding pollination, (c) nectar robbers, when birds probed the nectar by holes bitten in the calyces or corollas, (d) flower predators, when birds consumed floral tissue. The relative frequency of visits of each species was calculated as the number of visits performed by the species in relation to the total number of visits recorded, and denoted in percentage. Photographs were taken for analyses of bird visiting behavior.

\section{Data analysis}

We used parametric statistics whenever possible. Each data set was tested for normality (Shapiro-Wilk's test) and homogeneity of variances (Levine test). When these two criteria were not met even after data transformation, we used nonparametric tests. Differences among multiple means were tested by one-way ANOVA followed by Tukey HSD a posteriori comparisons or by the non-parametric Kruskal-Wallis rank sums test $(\mathrm{H})$ followed by Dunn MCP. We used Spearman correlation $\left(r_{s}\right)$ to test if sample size (number of flowers per sample) and coefficient of variation ([SD/mean].100) are negatively correlated in a way that larger sample sizes could yield more accurate estimates of population parameters (MCDADE \& WEEKS 2004a). Differences in rates of bird visitation among time intervals were investigated using the Chi-square test $\left(\chi^{2}\right)$. The Mann-Whitney test (U) and the Chi-square were used to compare the number of flowers probed per visit by different hummingbird species. Measurements of hummingbird bill lengths (culmen) were taken from specimens deposited in the Museum of the Campinas University (Unicamp, Campinas, Brazil) or in the Alexander Koenig Zoological Institute and Museum (Bonn, Germany). Data on hummingbird body mass were obtained in GrantSAu (1988).

\section{RESULTS}

\section{Cumulative nectar production and standing crop}

In previously bagged flowers, significant differences in cumulative nectar volume per flower among sample hours were not detected. Mean volumes ranged from $21 \mathrm{ml}$ to $31 \mathrm{ml}$. Sugar concentration followed a similar trend; it remained relatively constant throughout the day, with mean values ranging from $22 \%$ to $28.6 \%$. Although there were no significant differences among sample means, both nectar volume and sugar concentration fluctuated to some extent across the day (Tab. I), suggesting a combined process of periods in which nectar was slightly secreted (early morning and early afternoon) and reabsorbed (midday and mid-afternoon). Energetic content per 
Table I. Cumulative nectar production in Erythrina speciosa flowers throughout the day. Values are means, standard deviations (SD), number of flowers sampled $(\mathrm{N})$, and coefficients of variation $(\mathrm{CV}=[(\mathrm{SD} / \mathrm{mean}) .100])$. Results of ANOVA (F) comparisons are given in the last column.

\begin{tabular}{|c|c|c|c|c|c|c|}
\hline \multirow{2}{*}{ Nectar Feature } & \multicolumn{5}{|c|}{ Sample hour } & \multirow{2}{*}{ ANOVA } \\
\hline & 08:00 & $10: 00$ & $12: 00$ & $14: 00$ & $16: 00$ & \\
\hline \multicolumn{7}{|l|}{ Volume $(\mu \mathrm{l})$} \\
\hline Mean & 30.71 & 31.35 & 24.11 & 30.75 & 21.19 & $F 4,38=0.96, p=0.44$ \\
\hline SD & 16.79 & 16.49 & 13.55 & 13.11 & 9.71 & \\
\hline CV (\%) & 54.68 & 52.61 & 56.19 & 42.63 & 45.84 & \\
\hline $\mathrm{N}^{1}$ & 7 & 10 & 9 & 8 & 9 & \\
\hline \multicolumn{7}{|l|}{ Concentration (\%) } \\
\hline Mean & 28.60 & 26.34 & 22.10 & 27.63 & 24.34 & $F 4,38=1.55, p=0.21$ \\
\hline SD & 1.06 & 4.23 & 6.94 & 3.76 & 2.56 & \\
\hline CV (\%) & 3.70 & 16.08 & 31.41 & 13.61 & 10.51 & \\
\hline \multicolumn{7}{|l|}{ Joules per flower } \\
\hline Mean & 167.34 & 157.09 & 111.69 & 163.36 & 94.77 & $\mathrm{~F} 4,38=1.49, \mathrm{p}=0.22$ \\
\hline SD & 95.17 & 94.06 & 83.01 & 74.46 & 41.18 & \\
\hline CV (\%) & 56.87 & 59.88 & 74.33 & 45.58 & 43.56 & \\
\hline
\end{tabular}

${ }_{1}^{1}$ Sample sizes are the same for volume, concentration, and joules per flower.

flower ranged from 95-167 J. Coefficients of variation (CV) were comparatively lower for concentration than for volume and energetic content per flower.

Less nectar was available in flowers exposed to foragers than in protected flowers at any sample hour. Standing crop values for nectar volume and energetic content per flower were higher in the early morning and further declined. Sugar concentration did not change throughout the day (Tab. II). Standing crop was remarkably for variation among single flowers sampled at any one time, with CV often exceeding 100\% (with the exception of sugar concentration). Coefficients of variation for standing crop data often exceeded CV for cumulative nectar data. This was because the former had many zero and near-zero values (flowers emptied or with nectar depleted by foragers) and a few high values (flowers not recently visited or that were missed by foragers; Fig 1). The variability among flowers, as well as number of flowers empty of nectar, increased across the day (Tab. II, Fig. 1).

Coefficients of variation and sample sizes were not correlated for either cumulative nectar production or standing crop ( $p>0.22$ for all variables). Thus, the observed variations among single flowers are unlikely to be biased by the small sample sizes.

\section{Assemblage of bird visitors and visitation rates}

Seven hummingbird species and two passerine birds, the Bananaquit and the Sayaca Tanager - Thraupis sayaca Linnaeus, 1766 were observed, in a total of 211 feeding bouts (Tab. III). The Black Jacobin - Melanotrochilus fuscus Vieillot, 1817 and the Gilded-Sapphire Hummingbird - Hylocharis chrysura Shaw,

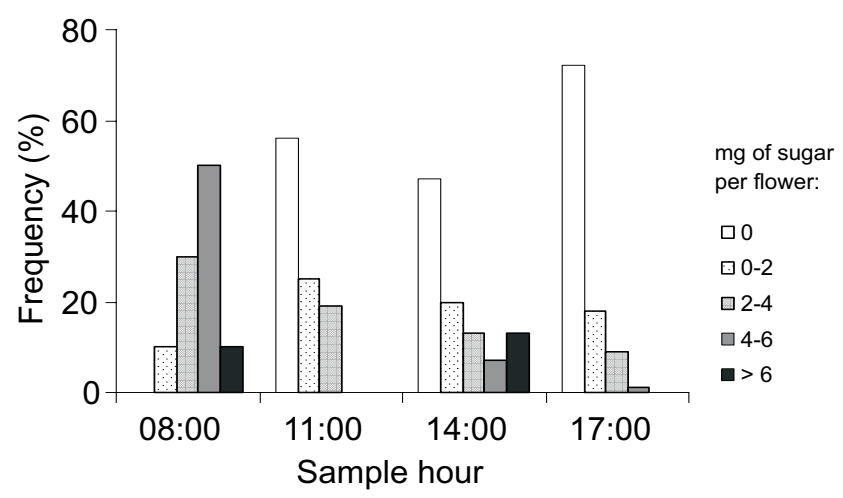

Figure 1. Nectar standing crop distribution in Eryhtrina speciosa, showing nectar availability in individual flowers ( $\mathrm{mg}$ of sugar) at different times of the day ( $n=12-16$ flowers per sample hour).

1812 were the most frequent, accounting together for up to $58 \%$ (about $30 \%$ for the former and $28 \%$ for the latter) of the total number of visits.

On the whole, birds were more frequent early in the day and their activity on flowers further declined $\left(\chi^{2}=108.01, \mathrm{df}=9\right.$, $\mathrm{p}<0.001$, Fig. 2). For example, up to $60 \%$ of the visits by $M$. fuscus were before 10:00 h and about $86 \%$ of its visits were performed before midday. Only $H$. chrysura foraged all day long $\left(\chi^{2}=9.64, p=0.38\right)$. Among hummingbirds most commonly observed, $M$. fuscus (9 g) probed a greater number of flowers per bout (mean $=24.8, \mathrm{SD}=19.7, \mathrm{n}=42$ ) than did the Sapphirespangled Emerald (5 g) - Amazilia lactea Lesson, 1832 and $H$. 
Table II. Standing crop of nectar in flowers of Erythrina speciosa. Values are means, standard deviations (SD), number of flowers sampled $(\mathrm{N})$, and coefficients of variation $(\mathrm{CV}=[(\mathrm{SD} /$ mean).100]). Results of Kruskal-Wallis $(\mathrm{K}-\mathrm{W}, \mathrm{H} ; \mathrm{df}=3)$ comparisons are presented in the last column. Values with the same letter are not significantly different by Dunn MCP at the Alfa level of 0.05 .

\begin{tabular}{|c|c|c|c|c|c|}
\hline \multirow{2}{*}{ Standing crop of nectar } & \multicolumn{4}{|c|}{ Sample hour } & \multirow{2}{*}{$\mathrm{K}-\mathrm{W}$} \\
\hline & 08:00 & $11: 00$ & $14: 00$ & $17: 00$ & \\
\hline \multicolumn{6}{|l|}{ Volume $(\mu \mathrm{l})$} \\
\hline Mean & $18.80^{\mathrm{a}}$ & $3.23 b$ & $7.18 b$ & $1.40 \mathrm{~b}$ & $H=20.10$, \\
\hline SD & 8.96 & 5.45 & 10.21 & 3.99 & $P=0.0002$ \\
\hline $\mathrm{N}^{1}$ & 10 & 16 & 15 & 11 & \\
\hline CV (\%) & 47.66 & 168.58 & 142.26 & 285.90 & \\
\hline \multicolumn{6}{|l|}{ Concentration (\%) } \\
\hline Mean & 21.78 & 18.97 & 24.73 & 20.37 & $\mathrm{H}=5.37$ \\
\hline SD & 6.63 & 4.21 & 4.09 & 6.44 & $P=0.14$ \\
\hline $\mathrm{N}^{2}$ & 10 & 7 & 8 & 3 & \\
\hline CV (\%) & 30.46 & 22.21 & 16.53 & 31.63 & \\
\hline \multicolumn{6}{|l|}{ Joules per flower } \\
\hline Mean & $85.35^{\mathrm{a}}$ & $11.23 b$ & $34.46 b$ & $6.95 b$ & $H=18.49$, \\
\hline SD & 77.90 & 18.94 & 57.19 & 21.99 & $P=0.0003$ \\
\hline CV (\%) & 1.28 & 168.64 & 165.97 & 316.57 & \\
\hline
\end{tabular}

1 Sample sizes are the same for volume and joules per flower; 2 Flowers with no nectar were not included in analysis.

Table III. Bird visitors to Erythrina speciosa, their visitation frequency ( $\mathrm{n}=211$ feeding bouts), visiting behavior, and bill lengths (only for hummingbirds). Values for bill lengths are means, standard deviations (SD), and number of specimens sampled (N). Results of ANOVA indicated that bill lengths differed among hummingbird species $(F 6,26=124.28, p<0.001)$. Means with the same letter are not significantly different by Tukey HSD a posteriori comparison at the Alfa level of 0.05 .

\begin{tabular}{|c|c|c|c|c|c|}
\hline \multirow{2}{*}{ Species } & \multirow{2}{*}{ VF (\%) } & \multirow{2}{*}{ Visiting behavior ${ }^{1}$} & \multicolumn{3}{|c|}{ Bill length (mm) } \\
\hline & & & Mean & SD & Sample size \\
\hline \multicolumn{6}{|l|}{ Trochilidae } \\
\hline Amazilia lactea & 14.69 & NT & $18.23^{a}$ & 0.59 & 5 \\
\hline Hylochrais chrysura & 27.96 & NT & $19.07^{\mathrm{a}}$ & 1.44 & 4 \\
\hline Eupetomena macroura & 0.95 & NT & $21.33^{a}$ & 0.84 & 10 \\
\hline Leucochloris albicollis & 3.32 & PP? & $21.90^{\mathrm{a}}$ & 0.48 & 3 \\
\hline Melanotrochilus fuscus & 30.33 & $\mathrm{PP}, \mathrm{NT}$ & $21.21^{\mathrm{a}}$ & 0.56 & 2 \\
\hline Phaethornis pretrei & 0.47 & PP & $32.43^{b}$ & 0.58 & 4 \\
\hline Heliomaster squamosus & 1.42 & PP & $30.18^{b}$ & 0.59 & 5 \\
\hline \multicolumn{6}{|l|}{ Emberezidae } \\
\hline Coereba flaveola & 6.64 & NR & - & - & - \\
\hline Thraupis sayaca & 14.22 & $N R, F P$ & - & - & - \\
\hline
\end{tabular}

1 Visiting behavior: (PP) potential pollinator, (NT) nectar thieve, (NR) nectar robber, (FP) flower predator.

chrysura $\left(4 \mathrm{~g}, \chi^{2}=8.37, \mathrm{df}=2, \mathrm{p}=0.01\right)$. The numbers of flowers probed per visit by the two smaller species were equivalent (mean $=11.8, \mathrm{SD}=8.5, \mathrm{n}=36$ and mean $=10.6, \mathrm{SD}=12.1, \mathrm{n}=42$, respectively, $\mathrm{U}=202.00, \mathrm{p}=0.28$ ).

\section{Visiting behavior of hummingbirds and perching birds}

The bird visitors to E. speciosa displayed different visiting-behaviors (Tab. III). Regarding hummingbirds, bill lengths significantly differed among species $\left(\mathrm{F}_{2,31}=124.28, \mathrm{p}<0.001\right)$ and, coupled to the mode to which birds approached the flowers, seemed to have highly influenced their role as pollinators; birds which visited the flowers only legitimately (acting as potential pollinators) have bills longer than $30 \mathrm{~mm}$.

The Planalto Hermit - Phaethornis pretrei Lesson \& Delattre, 1839 and the Stripe-breasted Starthroat - Heliomaster squamosus 


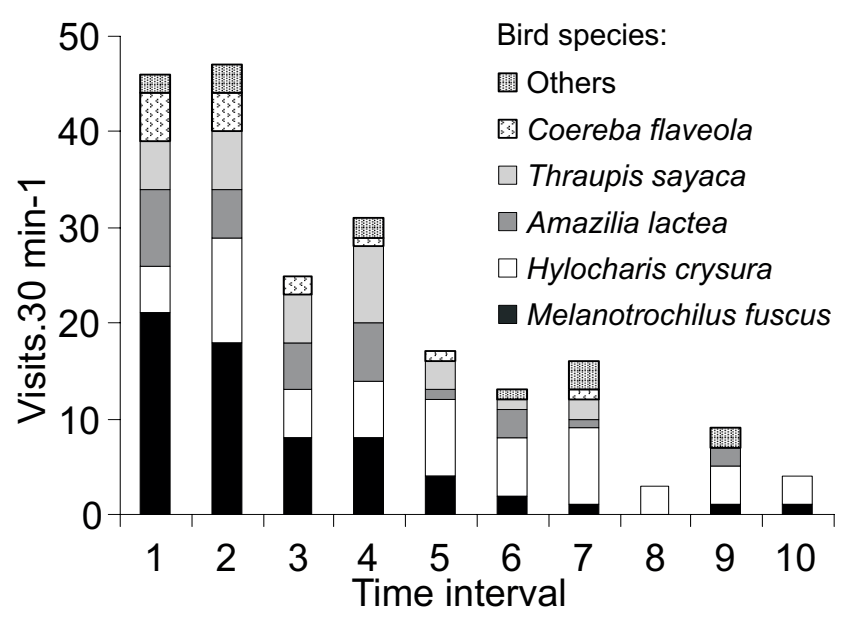

Figure 2. Rates of bird visitation (visits. $30 \mathrm{~min}^{-1}$ ) to flowers of Erythrina speciosa at different time intervals, between 8:00 and $17: 30 \mathrm{~h}$.

Temminck, 1823 (Fig. 3), which have bills longer than $30 \mathrm{~mm}$, effectively contacted anthers and stigma while probing for nectar, but were rarely observed. Melanotrochilis fuscus (bill length = $21 \mathrm{~mm}$; Fig. 4) inspected the flowers in both legitimate and illegitimate ways (nectar thieving). The White-throated Hummingbird - Leucochloris albicollis Vieillot, 1818 was rarely recorded. However, based on its bill length in relation to corolla length, this bird most probably acts as a pollinator or behaves in a manner similar to M. fuscus.

By approaching the flowers from below and inserting their bills in the base of the corolla or calyx opening, shortbilled hummingbirds essentially were nectar thieves. $H$. chrysura (Figs 5 and 6), A. lactea, and the Swallow-tailed Hummingbird - Eupetomena macroura Gmelin, 1788 were able to reach the nectar but never contacted the floral reproductive parts. Passerine birds always perched in the inflorescence axis or adjacent branches to access the flowers and essentially were nectar robbers. Thraupis sayaca obtained nectar by perforating the calyx (Fig. 7) and Coereba flaveola (Fig. 8) either pierced the calyx or probed previously made holes. Moreover, T. sayaca often behaved as a flower predator, consuming floral tissues in addition to nectar; in some occasions it removed the entire flower from the plant.

\section{Territory defense}

Aggressive displacements between hummingbirds were quite common ( $\mathrm{n}=42$ in 35 hours of observation), most involving $M$. fuscus. In few occasions we observed aggressive behavior among hummingbirds and perching birds. M. fuscus set up feeding territories in individuals of $E$. speciosa that were more profusely flowered and chased other hummingbirds from the flowers, especially conspecifics and A. lactea. In August, when flowering perceptibly declined, M. fuscus was less frequently observed and changed its foraging pattern. Instead of holding a static territory, the hummingbird visited E. speciosa at sporadic intervals, traplining among individuals.

In periods when $M$. fuscus was absent, $H$. chrysura and $A$. lactea defended the flowers; intra and interespecific chases between these two species have been observed. Among feeding bouts on $E$. speciosa, short-billed hummingbirds frequently used other nectar sources. H. chrysura and A. lactea were regularly seen feeding on clumps of Malvaviscus arboreus Cav. (Malvaceae), Stifftia chrysantha Mikan (Asteraceae) and Bauhinia variegata L. (Fabaceae).

\section{DISCUSSION}

\section{Cumulative nectar production and standing crop}

In protected flowers, nectar volume per flower and sugar concentration remained relatively constant throughout the day, suggesting that in the absence of removals by foragers, secretion may ceases or greatly reduces after a maximum volume has been reached (Cruden \& Herman 1983, Neill 1987). However, the occurrence of subtle variations on both volume and concentration during the day may imply the existence of periods of secretion and reabsorption. Moreover, removals of nectar by foragers may cause the resumption of secretion in $E$. speciosa; through repeated nectar samplings at the same flowers along the day, Almeida \& Alves (2003) observed that nectar is continuously secreted, with its greater production early in the morning.

We observed less nectar (volume and energetic content) in flowers exposed to foragers than on bagged flowers which presumably was due to consumption by foragers. Thus, our study agrees with previous observations that nectar in flowers opened to visitors often bears little relationship to nectar in bagged flowers (MCDADE \& WEEKS 2004b). This has important ecological consequences given that pollinators are likely to make foraging decisions based on encountered rewards (standing crop) rather than on potential rewards (MCDADE \& WeEKS 2004b). Additionally, as shown by CV, nectar quantities at single flowers were more variable in flowers open to visitors than on bagged flowers. The way in which foragers respond to variability in amount of reward has been addressed by theories on risk-sensitive foraging. Most experimental studies holding mean reward constant have shown that foragers prefer less variable rewards (Shafir 2000, Bateson 2002, Biernaskie et al. 2002). Our data do not allow us to test this idea, but in E. speciosa, early morning visitors are likely to be more profitable in foraging (and encouraged to forage) due to the greater nectar availability and lower variability among flowers.

\section{Assemblage of bird visitors and visitation rates}

Erythrina speciosa flowers mostly in the dry season and represents, during such period, an important nectar source in the study site, being visited by $c a$. 80 percent of the local hummingbird species (MENDONÇA \& Anjos 2005). The number of species at flowers of E. speciosa in the campus of the Londrina 

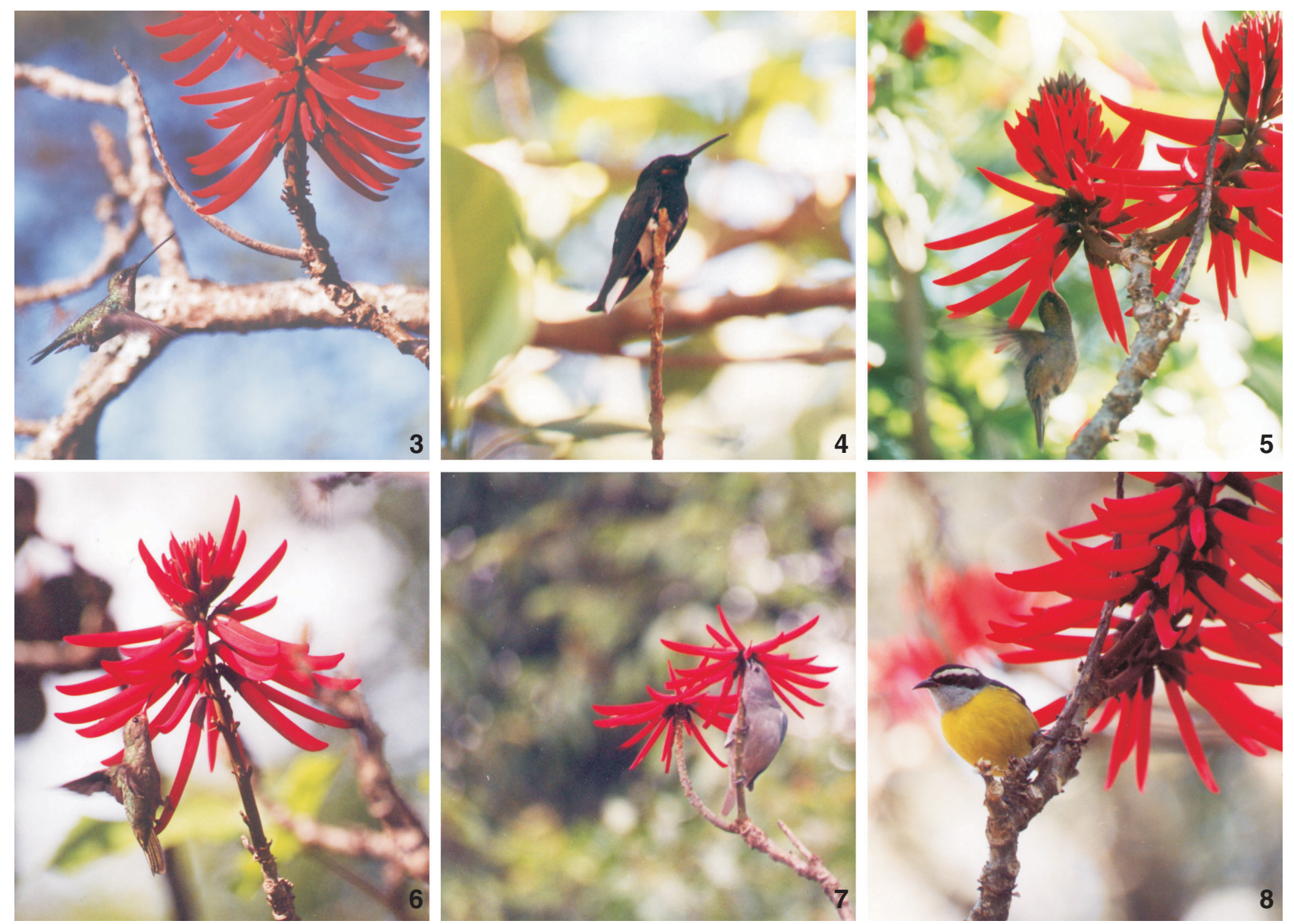

Figures 3-8. Flowers of Erythrina speciosa and bird visitors in the campus of Londrina State University, Londrina, Paraná, Brazil: the Stripbreasted Starthroat (Heliomaster squamosus) approaching the flowers (3); the Black Jacobin (Melanotrochilus fuscus) perched on a branch (4); the Gilded-Sapphire Hummingbird (Hylocharis chrysura) approaching the flowers from below and thieving nectar (5 and 6); the Sayaca Tanager (Thraupis sayaca) robbing nectar through holes bitten in the calyx (7); the Bananaquit (Coereba flaveola) perched on an inflorescence (8). Photographs are not at the same.

State University was higher than that reported for other sites (3 species: Vitalli-Veiga \& Machado 2000, 3: Almeida \& Alves 2003). Besides local patterns of species richness of hummingbirds, the flower abundance and the proximity between individuals are factors that may have contributed to plant attractiveness in our study site, increasing flower density.

On the whole, visits of both hummingbirds and perching birds corresponded to the period of greater nectar availability. Nectarivorous are sensitive to nectar availability in plants and can change their foraging behavior in response to reward supplies (Quirino \& MACHADO 2001). Thus, it is possible that the pattern of nectar secretion of E. speciosa, coupled to floral visitor activity depleting the nectar in the course of the day makes the foraging progressively less profitable in energetic terms (as discussed earlier in this paper). Besides declining nectar supplies along the day that a bird could encounter while foraging, there is an increasing variability in nectar content among flowers. Especially birds with higher energetic demands, like Melanotrochilus fuscus and the passerines, may have been discouraged to visit the flowers at such conditions. Actually, only the small, generalist Hylocharis chrysura did forage at flowers of E. speciosa with the same frequency throughout the day.

In each visit, $M$. fuscus probed twice as many flowers per bout than $H$. chrysura and Amazilia lactea. This could be related to the higher metabolic requirements of the former, since total daily energy cost increases with increasing body size, whatever the cost per gram (MCMiLlen \& CARPENTER 1977, BROWN et al. 1978).

Revista Brasileira de Zoologia 23 (1): 42-49, março 2006 


\section{Visiting behavior: morphological and behavioral constraints}

The long, tube-like corollas of E. speciosa flowers seem adapted to pollination by long-billed hummingbirds, as found for other Erythrina species with similar floral traits (FEINSINGER et al. 1979, Neill 1987). Nevertheless, as noted for other hummingbird-pollinated species (Hernández \& Toledo 1979, Navarro 1999), the frequency of visits from non-pollinating birds (up to $64 \%$ ) outnumbered those of potential pollinators.

The manner to which birds probed the flowers of $E$. speciosa was a great deal determined by morphological traits, in particular bill lengths (see Almeida \& Alves 2003), and approaching behavior of birds. The anatomical and behavioral fit of the animal and the flower represents an important feature amongst the several ones that determines whether a given anthophile is a pollinator (KeVAN 1999). In the present study, long-billed, traplining hummingbirds (Heliomaster squamosus and Phaethornis pretrei) were likely to be the most able to pollinate $E$. speciosa flowers. However, they were characterized by their remarkably low number of visits. It is possible that the visitation of these birds to E. speciosa was reduced by the monopolization of flowers by the bellicose M. fuscus. Aggressive behavior of dominant individuals or species can result in partial or complete exclusion of subordinate individuals or species from flowers that they might otherwise visit (STILES 1981, see also Martinez del Rio \& Eguiarte 1987).

Although M. fuscus acted both as a legitimate visitor and nectar thieve, it was the most frequent visitor, and may play some role on pollination of E. speciosa. Almeida \& Alves (2003) have also mentioned the possibility of pollination of this plant by medium-billed hummingbirds such as the Violet-capped Woodnymph - Thalurania glaucopis Gmelin, 1788 and the Glittering-throated Emerald - Amazilia fimbriata Gmelin, 1788 that, as $M$. fuscus, exploited the flowers both legitimately and illegitimately. Nectar-thieving hummingbirds and passerine robbers had the shorter bills. Nectar thieving normally happens due to a mismatch between visitor morphology and the floral architecture, and the animal obtains the nectar but does not touch anthers or stigma (INOUYE 1980). Corolla length and shape greatly limit visitor access (KeARNS \& INOUYE 1993), but in several Eryhtrina species short-billed, nectar-thieving hummingbirds may take advantage of the incompletely sealed corolla tube to reach the nectar (NeILL 1987).

Unlike hummingbirds, passerines obtained nectar by holes in the calyx. Such birds have bills that are wider and shorter than those of hummingbirds, which probably preclude them to access the nectar of E. speciosa in a way other than perforating the flower (INOUYE 1983). The distinction between nectar thieves and robbers is important because the latter may have a greater effect in reducing the reproductive potential of the plant by damaging sexual tissues and often destroying or removing the entire flower (Neill 1987, Traveset et al. 1998, Lara \& Ornelas 2001, Ragusa-NetTo 2002). Nectar robbing by $T$. sayaca often did cause reproductive tissue damage.

\section{Territory defense}

Neill (1987) has assumed that hummingbird-adapted Erythrina species, even at the peak of flowering, do not produce enough nectar to support territorial defense by hummingbirds. Our observations did not support this prediction. Most hummingbird visitors exhibited territorial behavior, with emphasis to M. fuscus that, due to its high frequency and aggressiveness, may be considered an organizing species. Small, short-billed hummingbirds also defended the flowers. Besides nectar characteristics of E. speciosa, the massive flowering and the proximity of individuals in the studied population enhance the amount of nectar available in a limited space, favoring the establishment of feeding territories (STILEs 1978, SAZIma et al. 1996).

Erythrina speciosa consists in an important feeding source for animals in the urban site during the winter and, with a careful planning, would serve as a management instrument to conserve nectarivorous birds in urban areas. Given that the flower availability and nectar supplies affect the feeding behavior of birds on flowers, future comparisons between populations of E. speciosa with different plant densities may be of interest to better understand patterns of nectar availability, bird foraging behavior, and visitation rates.

\section{ACKNOWLEDGEMENTS}

We are grateful to E.B. Mendonça and M.G. Ballarotti for helping with nectar measurements in the field, to E.V. Lopes that kindly authorized the use his photograph of Heliomaster squamosus, and to R.J. Donatelli and an anonymous reviewer for valuable comments on the manuscript. We appreciate the improvements in English usage made by Michelle Hancock.

\section{REFERENCES}

AlmeIDA, E.M. \& M.A.S. Alves. 2003. Comportamento de aves nectarívoras em Erythrina speciosa Andrews (Leguminosae-Papilionoideae) em uma área de Floresta Atlântica, Ilha Grande, Rio de Janeiro. Revista de Etologia, São Paulo, 5 (1): 15-21.

BAKER, H.G. \& I. BAKER. 1983. Floral nectar sugar constituents in relation to pollinator type, p. 117-214. In: C. E. JonEs \& R.J. LitTLE (Eds). Handbook of experimental pollination biology. New York, van Nostrand Reinhold Company, 558p.

BAKER, H.G. \& I. BAKER. 1990. The predictive value of nectar chemistry to the recognition of pollinator types. Israel Journal of Botany, Jerusalem, 39: 157-166.

BAKER, H.G.; I. BAKER \& S.A. Hodges. 1998. Sugar composition of nectars and fruits consumed by birds and bats in the tropics and subtropics. Biotropica, Lawrence, 30 (4): 559-586.

BATESON, M. 2002. Recent advances in our understanding of risksensitive foraging preferences. Proceedings of the Nutrition Society, Wallingford, 61 (4): 509-516.

Biernaskie, J.M.; R.V. Cartar \& T.A. Hurly. 2002. Risk-averse inflorescence departure in hummingbirds and bumble bees: could plants benefit from variable nectar volumes? Oikos, 
Copenhagen, 98 (1): 98-104.

Brown, J.H.; W.A. Calder \& A. Kodrick-Brown. 1978. Correlates and consequences of body size in nectar-feeding birds. American Zoologist, Lawrence, 18 (4): 687-700.

Cruden, R.W. \& S.M. Hermann. 1983. Studying nectar? Some observations on the art, p. 223-241. In: B. Bentley \& T. Elias (Eds). The biology of nectaries. New York, Columbia University Press, 259p.

DAfNI, A. 1992. Pollination ecology: a practical approach. Oxford, Oxford University Press, 250p.

Feinsinger, P. \& R.K. Colwell. 1978. Community organization among Neotropical nectar-feeding birds. American Zoologist, Lawrence, 18 (4): 779-795.

Feinsinger, P.; Y.B. LinharT; L.A. Swarm \& J.A. Wolfe. 1979. Aspects of the pollination biology of three Erythrina species on Trinidad and Tobago. Annals of the Missouri Botanical Garden, St. Louis, 66 (3): 451-471.

Franceschinelli, E.V. \& K.S. BAWA. 2000. The effect of ecological factors on the mating system of south american shrub species (Helicteres brevispira). Heredity, Oxford, 84 (1): 116-123.

Grantsau, R. 1988. Os beija-flores do Brasil: uma chave de identificação para todas as formas de beija-flores do Brasil. Rio de Janeiro, Editora Expressão e Cultura, 233p.

Hernandez, H.M. \& V.M. Toledo. 1979. The role of nectar robbers and pollinators in the reproduction of Erytrhina leptorhiza. Annals of the Missouri Botanical Garden, St. Louis, 66 (3): 512-520

Inouye, D.W. 1980. The terminology of floral larceny. Ecology, Washington, 61 (5): 1251-1253.

INOuYe, D.W. 1983. The ecology of nectar robbing, p. 153-174. In: B. Bentley \& T. Elias (Eds). The biology of nectaries. New York, Columbia University Press, 259p.

Kearns, C.A. \& D.W. Inouye. 1993. Techniques for pollination biologists. Niwot, University Press of Colorado, 583p.

Kevan, P.G. 1999. Pollinators as bioindicators of the state of the environment: species, activity and diversity. Agriculture, Ecosystems and Environment, Amsterdam, 74 (1-3): 373 393.

Lara, C. \& J.F. Ornelas. 2001. Preferential nectar robbing of flowers with long corollas: experimental studies of two hummingbird species visiting three plant species. Oecologia, New York, 128 (2): 263-273.

Martinez del Rio, C. \& L.E. Eguiarte. 1987. Bird visitation to Agave salmiana: comparisons among hummingbirds and perching birds. Condor, Lawrence, 89 (2): 357-363.

MCDADE, L.A. \& J.A. WEeKs. 2004a. Nectar in hummingbirdpollinated Neotropical plants I: patterns of production and variability in 12 species. Biotropica, Lawrence, 36 (2): 196215.

McDADE, L.A. \& J.A. WeEKS. 2004b. Nectar in hummingbirdpollinated Neotropical plants II: interactions with flower visitors. Biotropica, Lawrence, 36 (2): 216-220.

McMillen, R. E. \& F. L. Carpenter. 1977. Daily energy costs and body weight in nectarivorous birds. Comparative Biochemistry and Physiology, Oxford, 56A (3): 439-441.

MendonçA, L.B. \& L. Dos Anjos. 2005. Beija-flores (Aves, Trochilidae) e seus recursos florais em uma área urbana do sul do Brasil. Revista Brasileira de Zoologia, Curitiba, 22 (1): 51-59.

Murcia, C. \& P. Feinsinger. 1996. Interespecific polen loss by hummingbirds visiting flower mixtures: effects of floral architecture. Ecology, Washington, 77 (2): 550-560.

Navarro, L. 1999. Pollination ecology and effect of nectar removal in Macleania bullata (Ericaceae). Biotropica, Lawrence, 31 (4):618-625.

NeILL, D.A. 1987. Trapliners in trees: hummingbird pollination of Erythrina SECT. Erythrina (Leguminosae: Papilionoideae). Annals of the Missouri Botanical Garden, St. Louis, 74 (1): 27-41.

Quirino, Z.G.M. \& I.C. Machado. 2001. Biologia da polinização e da reprodução de três espécies de Combretum Loefl. (Combretaceae). Revista Brasileira de Botânica, São Paulo, 24 (2): 181-193.

Ragusa-NetTo, J. 2002. Exploitation of Eryhtrina dominguezii Hassl. (Fabaceae) nectar by perching birds in a dry forest in western Brazil. Brazilian Journal of Biology, Rio de Janeiro, 62 (4B): 877-883.

SAzima, M., S. BuZATo \& I. SAzima. 1996. An assemblage of hummingbird-pollinated flowers in a montane forest in southeastern Brazil. Botanica Acta, Stuttgart, 109 (2): 149-160.

SHAfIR, S. 2000. Risk-sensitive foraging: the effect of relative variability. Oikos, Copenhagen, 88 (3): 663-669.

STEINER, K.E. 1979. Passerine pollination of Erythrina megistophyla Diels (Fabaceae). Annals of the Missouri Botanical Garden, St. Louis, 66 (3): 490-502.

STILES, F.G. 1978. Ecological and evolutionary implications of bird pollination. American Zoologist, Lawrence, 18 (4): 715 727.

STILES, F.G. 1981. Geographical aspects of bird-flower coevolution, with particular reference to Central America. Annals of the Missouri Botanical Garden, St. Louis, 68 (2): 323-351.

Traveset, A.; M.F. Willson \& C. SAbag. 1998. Effect of nectarrobbing birds on fruit set of Fuchsia magellanica in Tierra del Fuego: a disrupted mutualism. Functional Ecology, Oxford, 12 (3): 459-464.

Vitali-Veiga, M.J. \& V.L.L. Machado. 2000. Visitantes florais de Erythrina speciosa Andr. (Leguminosae). Revista Brasileira de Zoologia, Curitiba, 17 (2): 369-383.

WASER, N.M. 1983. The adaptive nature of floral traits: ideas and evidence, p. 241-285. In: L. Real (Ed.). Pollination Biology. Orlando, Academic Press, 338p.

WesterkAMP, C. 1990. Bird-flowers: hovering versus perching exploitation. Botanica Acta, Stuttgart, 103 (4): 366-371.

Received in 06.V.2005; accepted in 20.XI.2005.

Revista Brasileira de Zoologia 23 (1): 42-49, março 2006 